\title{
64. OPAQUE MINERALS IN BASALTS FROM HOLES 417D AND 418A
}

\author{
A. D. Genkin, I. P. Laputina, and N. N. Pertsev, \\ Institute of Geology of the Ore Deposits, Petrography, Mineralogy, and Geochemistry, \\ USSR Academy of Sciences, Moscow, USSR
}

\section{INTRODUCTION}

Opaque minerals constitute an important part of the basalts under study. Analysis of opaque minerals can provide a fuller understanding of some processes during congelation of basalts, as well as on the peculiarities of low-temperature alteration of basalts. Although this investigation is limited to consideration of 27 specimens (Table 1), its results reflect main features of the ore mineralogy at Sites 417 and 418.

The assemblages of opaque minerals in basalts, the composition of individual minerals, and their grain sizes depend chiefly on two factors: (1) the rate of cooling which determines the grain size of rock-forming and opaque minerals, and the texture of the rocks; and (2) the degree of secondary alteration. There is distinct correlation between degree of alteration and grain size. The coarser grained basalts are found in fresher rocks; fine-grained basalts usually are quite altered. The primary and secondary opaque mineral assemblages distribution also depends upon this regularity.

We have found the following primary opaque minerals in basalts: titanomagnetite, ilmenite, chromite, pyrrhotite, chalcopyrite, and pentlandite. The most widespread secondary opaque mineral is pyrite. Chalcopyrite, marcasite, and iron hydroxides were also noted.

We have observed primary sulfides only in less-altered coarse-grained basalts (Samples 417D-69-1, $142 \mathrm{~cm}$ and $418 \mathrm{~A}-85-1,33 \mathrm{~cm})$; altered basalts contain only pyrite and chalcopyrite.

\section{PRIMARY OPAQUE MINERALS}

\section{Titanomagnetite}

Titaniferous magnetite is the most widespread opaque mineral in the basalts studied. The groundmass of basalts (predominately fine-grained with plagioclase, olivine, and pyroxene phenocrysts) contains numerous, very small ( 20 to $50 \mu \mathrm{m}$ ) skeletal magnetite crystals (Plate 1, Figures 1 and $2)$. One can see the delicate form of these crystals at great magnifications. Very minute grains $(<1 \mu \mathrm{m})$ of magnetite are present adjacent to these skeletal crystals (Plate 1, Figure 2). Magnetite phenocrysts are very rare in the basalts and occur in small euhedral grains up to $100 \mu \mathrm{m}$.

These correlations suggest that the precipitation of magnetite from basalt melt began simultaneously with the formation of silicate phenocrysts and ended with consolidation of the groundmass. Minute magnetite grains, ranging in size from 1 to $7 \mathrm{~mm}$, occur in coarse-grained basalts, too. They are located in interstitial fine-grained mesostasis be- tween coarse grains of plagioclase, pyroxene, olivine, and magnetite (Plate 1, Figure 3). Rounded, elongated, locally euhedral forms of these fine grains of magnetite are observable under magnification (Plate 1, Figure 4).

Fine-grained skeletal magnetite grains frequently form crescentic fillings around small vesicles (Plate 2, Figure 1a, b) possibly due to a flotation effect. The meniscus of such fillings have the same orientation in thin section, giving evidence of their origin in liquid groundmass.

Larger (1 $\mathrm{mm}$ and more) euhedral magnetite grains are characteristic for coarse-grained basalts (Samples 417D67-7, $74 \mathrm{~cm}$; 417D-69-1, $142 \mathrm{~cm}$; 418A-79-1, $113 \mathrm{~cm}$; and $418 \mathrm{~A}-85-1,33 \mathrm{~cm})$. They occur preferentially along the grain boundaries of plagioclase and pyroxene (Plate 2, Figure 2). The biggest magnetite grains, which sometimes are located in mesostasis, have skeletal forms (Plate 2, Figure 3) and contain inclusions of solidificated residual basalt melt. Smaller skeletal magnetite crystals, with minute $(\sim 1$ $\mu \mathrm{m}$ ) sulfide globules adhered (Plate 2, Figure 4), are also found in the mesostasis.

The optic investigation of the coarse-grained magnetite at magnifications of 500 to $1000 \times$ shows that there are lamellar ilmenite intergrowths, sometimes up to 5 to $7 \mu \mathrm{m}$ across (Plate 3, Figure 1). Thicker ilmenite plates are rare (Plate 3, Figure 2). Most commonly, the width of the plates does not exceed 1 to $2 \mu \mathrm{m}$ (Plate 3, Figure 3).

Investigators of Mid-Atlantic Ridge (MAR) basalts recovered during DSDP Leg 37 (Wayman and Evans, 1977; Hall and Fisher, 1977) have pointed out the lack of ilmenite in the magnetites, when compared to terrestrial basalts with ilmenite-magnetite intergrowths. Wayman and Evans (1977) have not found any compositional inhomogeneity in dendritic magnetite grains, even at 10,000 $\times$ magnification under an electron microscope, and have concluded that the lack of ilmenite in submarine basalts results from the characteristics of their cooling and oxidation. Earlier studies of dredged MAR basalts (Carmichael, 1970) have shown, however, that coarse-grained varieties usually contain magnetite-ilmenite intergrowths and even separate ilmenite grains.

We have determined the composition of titanomagnetites, as well as other opaque minerals, by means of electron microprobe analysis. Microprobe analysis results for both fine skeletal and large titanomagnetite grains without optically visible ilmenite inclusions are given in Table 2 . Abnormal sums and rather high $\mathrm{SiO}_{2}, \mathrm{Al}_{2} \mathrm{O}_{3}$, and $\mathrm{MgO}$ contents in minute skeletal magnetites appear to be connected with the capture of adjacent silicates by the microprobe. 
TABLE 1

Basalt Samples Selected for Opaque Mineralogy Study

\begin{tabular}{|c|c|c|c|}
\hline $\begin{array}{c}\text { Sample } \\
\text { (Interval in } \mathrm{cm} \text { ) }\end{array}$ & Unit & Rock Type & Opaque Minerals \\
\hline $417 \mathrm{D}-48-6,86$ & $8 \mathrm{a}$ & $\begin{array}{l}\text { Medium-grained, moderately } \\
\text { altered basalt with phenocrysts } \\
\text { of plagioclase and olivine }\end{array}$ & $\left\{\begin{array}{l}\text { Titanomagnetite }{ }^{\mathrm{ab}} \\
\text { Pyrite } \\
\text { Chalcopyrite }\end{array}\right.$ \\
\hline 417D-49-1, 69 & $8 \mathrm{~b}$ & $\begin{array}{l}\text { Medium-grained, moderately } \\
\text { altered basalt with phenocrysts } \\
\text { of plagioclase and olivine }\end{array}$ & $\left\{\frac{\text { Titanomagnetite }}{\text { Pyrite }}\right.$ \\
\hline $417 \mathrm{D}-49-2,82$ & $8 \mathrm{~b}$ & $\begin{array}{l}\text { Medium-grained, moderately } \\
\text { altered basalt with phenocrysts } \\
\text { of plagioclase and olivine }\end{array}$ & $\frac{\text { Titanomagnetite }}{\text { Iron hydroxides }}$ \\
\hline 417D-50-1, 95 & $8 b$ & $\begin{array}{l}\text { Fine-grained, moderately al- } \\
\text { tered basalt with phenocrysts } \\
\text { of plagioclase, pyroxene, and } \\
\text { olivine }\end{array}$ & $\begin{array}{l}\text { Titanomagnetite }{ }^{\mathrm{a}} \\
\text { Iron hydroxides } \\
\text { Pyrite }\end{array}$ \\
\hline $417 D-52-4,13$ & $9 \mathrm{a}$ & $\begin{array}{l}\text { Fine-grained, moderately al- } \\
\text { tered basalt with phenocrysts } \\
\text { of plagioclase, pyroxene, and } \\
\text { olivine }\end{array}$ & $\begin{array}{l}\text { Titanomagnetite } \\
\text { Pyrite } \\
\text { Marcasite }\end{array}$ \\
\hline $417 \mathrm{D}-54-5,46$ & $9 \mathrm{a}$ & $\begin{array}{l}\text { Fine-grained, moderately al- } \\
\text { tered basalt with phenocrysts } \\
\text { of plagioclase, pyroxene, } \\
\text { olivine }\end{array}$ & $\begin{array}{l}\text { Titanomagnetite } \\
\text { Pyrite } \\
\text { Marcasite } \\
\text { Chalcopyrite }\end{array}$ \\
\hline 417 D-59-3, 104 & $9 \mathrm{~b}$ & $\begin{array}{l}\text { Fine-grained, moderately altered } \\
\text { basalt with phenocrysts of } \\
\text { plagioclase, pyroxene, olivine }\end{array}$ & $\begin{array}{l}\text { Titanomagnetite } \\
\text { Pyrite } \\
\text { Chalcopyrite }\end{array}$ \\
\hline $417 \mathrm{D}-62-4,58$ & 9 & $\begin{array}{l}\text { Fine-grained, moderately to } \\
\text { badly altered basalt with } \\
\text { phenocrysts of plagioclase, } \\
\text { pyroxene and olivine }\end{array}$ & Titanomagnetite ${ }^{a}$ \\
\hline 417D-63-5, 24 & 9 & $\begin{array}{l}\text { Fine-grained, moderately to } \\
\text { badly altered basalt with } \\
\text { phenocrysts of plagioclase, } \\
\text { pyroxene and olivine }\end{array}$ & $\begin{array}{l}\text { Pyrite } \\
\text { Chalcopyrite }\end{array}$ \\
\hline $417 \mathrm{D}-64-3,33$ & 9 & $\begin{array}{l}\text { Fine-grained, moderately to } \\
\text { badly altered basalt with } \\
\text { phenocrysts of plagioclase, } \\
\text { pyroxene and olivine }\end{array}$ & Pyrite \\
\hline $417 \mathrm{D}-64-4,99$ & $10 \mathrm{a}$ & $\begin{array}{l}\text { Fine-grained, moderately to } \\
\text { badly altered basalt with } \\
\text { phenocrysts of plagioclase, } \\
\text { pyroxene and olivine }\end{array}$ & $\begin{array}{l}\text { Titanomagnetite } \\
\text { Pyrite } \\
\text { Chalcopyrite }\end{array}$ \\
\hline $417 \mathrm{D}-66-5,123$ & 11 & $\begin{array}{l}\text { Fine-grained, moderately to } \\
\text { badly altered basalt with } \\
\text { phenocrysts of plagioclase, } \\
\text { pyroxene and olivine }\end{array}$ & $\frac{\text { Titanomagnetite }}{\text { Pyrite }}$ \\
\hline $417 \mathrm{D}-67-3,11$ & 12 & $\begin{array}{l}\text { Fine-grained, moderately to } \\
\text { badly altered basalt with } \\
\text { phenocrysts of plagioclase, } \\
\text { pyroxene and olivine }\end{array}$ & $\begin{array}{l}\text { Titanomagnetite } \\
\text { Pyrite } \\
\text { Chalcopyrite }\end{array}$ \\
\hline 417 D- $67-7,74$ & 13 & $\begin{array}{l}\text { Medium-grained phyric basalt, } \\
\text { moderately altered with } \\
\text { phenocrysts of plagioclase }\end{array}$ & $\begin{array}{l}\text { Titanomagnetite } \\
\text { llmenite } \\
\text { Pyrrhotite } \\
\text { Pyrite } \\
\text { Chalcopyrite }\end{array}$ \\
\hline $417 \mathrm{D}-69-1,142$ & 13 & $\begin{array}{l}\text { Medium-grained phyric basalt, } \\
\text { moderately altered with } \\
\text { phenoctysts of plagioclase }\end{array}$ & $\left\{\begin{array}{l}\text { Titanomagnetite } \\
\text { llmenite } \\
\text { Pyrrhotite } \\
\text { Chalcopyrite }\end{array}\right.$ \\
\hline $418 \mathrm{~A}-57-4,136$ & $8 c$ & $\begin{array}{l}\text { Fine-grained badly altered } \\
\text { basalt with phenocrysts of } \\
\text { plagioclase and olivine }\end{array}$ & $\left\{\begin{array}{l}\text { Titanomagnetite } \\
\text { Pyrrhotite + Chalcopyrite } \\
\text { Pyrite }\end{array}\right.$ \\
\hline $418 \mathrm{~A}-58-1,8$ & $8 c$ & $\begin{array}{l}\text { Fine-grained badly altered } \\
\text { basalt with phenocrysts of } \\
\text { plagioclase and olivine }\end{array}$ & $\frac{\text { Titanomagnetite }}{\text { Pyrite }}$ \\
\hline $418 \mathrm{~A}-58-4,143$ & $8 \mathrm{c}$ & $\begin{array}{l}\text { Fine-grained badly altered } \\
\text { basalt with phenocrysts of } \\
\text { plagioclase and olivine }\end{array}$ & Pyrite \\
\hline $418 \mathrm{~A}-68-2.108$ & 13 & $\begin{array}{l}\text { Fine-grained, moderately al- } \\
\text { tered basalt with phenocrysts } \\
\text { of plagioclase, pyroxene and } \\
\text { forsterite }\end{array}$ & $\begin{array}{l}\text { Titanomagnetite } \\
\text { Pyrite } \\
\text { Chalcopyrite }\end{array}$ \\
\hline $418 \mathrm{~A}-69-1.57$ & 13 & $\begin{array}{l}\text { Fine-grained, moderately al- } \\
\text { tered basalt with phenocrysts } \\
\text { of plagioclase. pyroxene and } \\
\text { forsterite }\end{array}$ & $\begin{array}{l}\text { Titanomagnetite }{ }^{\mathrm{a}} \\
\text { Pyrite } \\
\text { Chalcopyrite }\end{array}$ \\
\hline $418 \mathrm{~A}-69-3,139$ & 13 & $\begin{array}{l}\text { Fine-grained, moderately al- } \\
\text { tered basalt with phenocrysts } \\
\text { of plagioclase, pyroxene and } \\
\text { forsterite }\end{array}$ & $\frac{\text { Titanomagnetite }}{\text { Pyrite }}$ \\
\hline $418 \mathrm{~A}-69-5.99$ & 13 & $\begin{array}{l}\text { Fine-grained, moderately al- } \\
\text { tered basalt with phenocrysts } \\
\text { of plagioclase. pyrovene and } \\
\text { forsterite }\end{array}$ & $\begin{array}{l}\text { Titanomagnetite } \\
\text { Pyrite } \\
\text { Chalcopyrite }\end{array}$ \\
\hline
\end{tabular}

TABLE 1 - Continued

\begin{tabular}{|c|c|c|c|}
\hline $\begin{array}{c}\text { Sample } \\
\text { (Interval in cm) }\end{array}$ & Unit & Rock Type & Opaque Minerals \\
\hline $418 \mathrm{~A}-74-4,90$ & 13 & $\begin{array}{l}\text { Fine-grained, moderately al- } \\
\text { tered basalt with phenocrysts } \\
\text { of plagioclase, pyroxene and } \\
\text { forsterite }\end{array}$ & $\frac{\text { Titanomagnetite }}{\text { Pyrite }}$ \\
\hline $418 \mathrm{~A}-77-1,87$ & $14 \mathrm{~b}$ & $\begin{array}{l}\text { Aphyric fine-grained basalt, } \\
\text { moderately altered }\end{array}$ & Pyrite \\
\hline $418 \mathrm{~A}-79-1,113$ & $14 \mathrm{~b}$ & $\begin{array}{l}\text { Coarse-grained basalt aphyric, } \\
\text { moderately altered }\end{array}$ & $\frac{\text { Titanomagnetite }}{\text { Pyrite }}$ \\
\hline $418 \mathrm{~A}-79-6,60$ & $14 \mathrm{~b}$ & $\begin{array}{l}\text { Coarse-grained basalt aphyric, } \\
\text { moderately altered }\end{array}$ & $\begin{array}{l}\text { Titanomagnetite } \\
\text { Pyrrhotite } \\
\text { Chalcopyritef }\end{array}$ \\
\hline $418 \mathrm{~A}-85-1,33$ & $14 \mathrm{c}$ & $\begin{array}{l}\text { Coarse-grained basalt aphyric, } \\
\text { moderately altered }\end{array}$ & $\begin{array}{l}\text { Chromite } \\
\text { Titanomagnetite }{ }^{b}+\text { ilmenite } \\
\text { Ilmenite } \\
\text { Pyrrhotite } \\
\text { Chalcopyrite } \\
\text { Cubanite } \\
\text { Pentlandite } \\
\end{array}$ \\
\hline 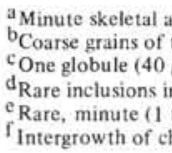 & $\begin{array}{l}\text { nd point } \\
\text { titanoma } \\
\mu \mathrm{m}) \text { in p } \\
\text { phenoc } \\
\text { to } 5 \mu \mathrm{m} \text { ) } \\
\text { alcopyr }\end{array}$ & $\begin{array}{l}\text {-grains of titanomagnetite. } \\
\text { agnetite, locally with ilmenite la } \\
\text { henocryst of plagioclase. } \\
\text { rysts of plagioclase. } \\
\text { globules in the mesostasis. } \\
\text { ite and pyrrhotite in a coarse gr }\end{array}$ & $\begin{array}{l}\text { lae. } \\
\text { of plagioclase. }\end{array}$ \\
\hline
\end{tabular}

We recalculated total iron in the titanomagnetite and ilmenite analyses using the techniques described by Carmichael (1967).

The distinct feature of all titanomagnetites studied is high ulvospinel content. This conclusion is supported by X-ray investigation. Unit cell size obtained, $\mathrm{a}=8.47 \AA$, is close to the ulvospinel unit cell.

A very thin inclusion in a magnetite grain of Sample 417D-69-1, $142 \mathrm{~cm}$ was found during the microprobe analyses. It consists of the following: $\mathrm{FeO}$ (total) $=8.55$, $\mathrm{TiO}_{2}=63.0, \mathrm{Cr}_{2} \mathrm{O}_{3}=0.97, \mathrm{MgO}=4.05, \mathrm{MnO}=0.1$, $\mathrm{SiO}_{2}=9.4, \mathrm{Al}_{2} \mathrm{O}_{3}=2.0$, and $\mathrm{V}_{2} \mathrm{O}_{5}=1.1$, for a total of 89.14 weight per cent.

\section{Ilmenite}

We observed ilmenite only in coarse-grained basalts. It occurs as lamellar inclusions in titanomagnetite grains (Plate 3, Figures 1 to 3). Minute separate grains of ilmenite are found by microprobe investigation in the fine-grained interstitial mesostasis of the basalts.

We determined the composition of the lamellar ilmenites and the titanomagnetite matrix. The microprobe analyses of four co-existing titanomagnetite-ilmenite pairs are given in Table 3. Mole percents of ulvospinel in magnetite and $\mathrm{R}_{2} \mathrm{O}_{3}$ $=\mathrm{Fe}_{2} \mathrm{O}_{3}+\mathrm{V}_{2} \mathrm{O}_{3}+\mathrm{Cr}_{2} \mathrm{O}_{3}+\mathrm{Al}_{2} \mathrm{O}_{3}$ in ilmenite also are listed in Table 3. Minor element distribution within these co-existing pairs shows that titanomagnetite contains more vanadium and aluminum, and less magnesium in comparison with ilmenite.

Experimental data (Buddington and Lindsley, 1964) give an opportunity to evaluate temperature and oxygen fugacity in equilibrium in magnetite-ilmenite pairs. These values, obtained from the Buddington and Lindsley diagram as well as data from the corrected diagram (Poltavets, 1975), are provided in Table 3 . Titanomagnetite exsolution in coarsegrained basalts confirms lower rates of cooling as compared to basalts with fine-grained groundmass. Lack of exsolution phenomena in the skeletal magnetite crystals found in interstitial mesostasis of the coarse-grained basalts (Plate 2, Fig- 
TABLE 2

Microprobe Analy ses of Titanomagnetite

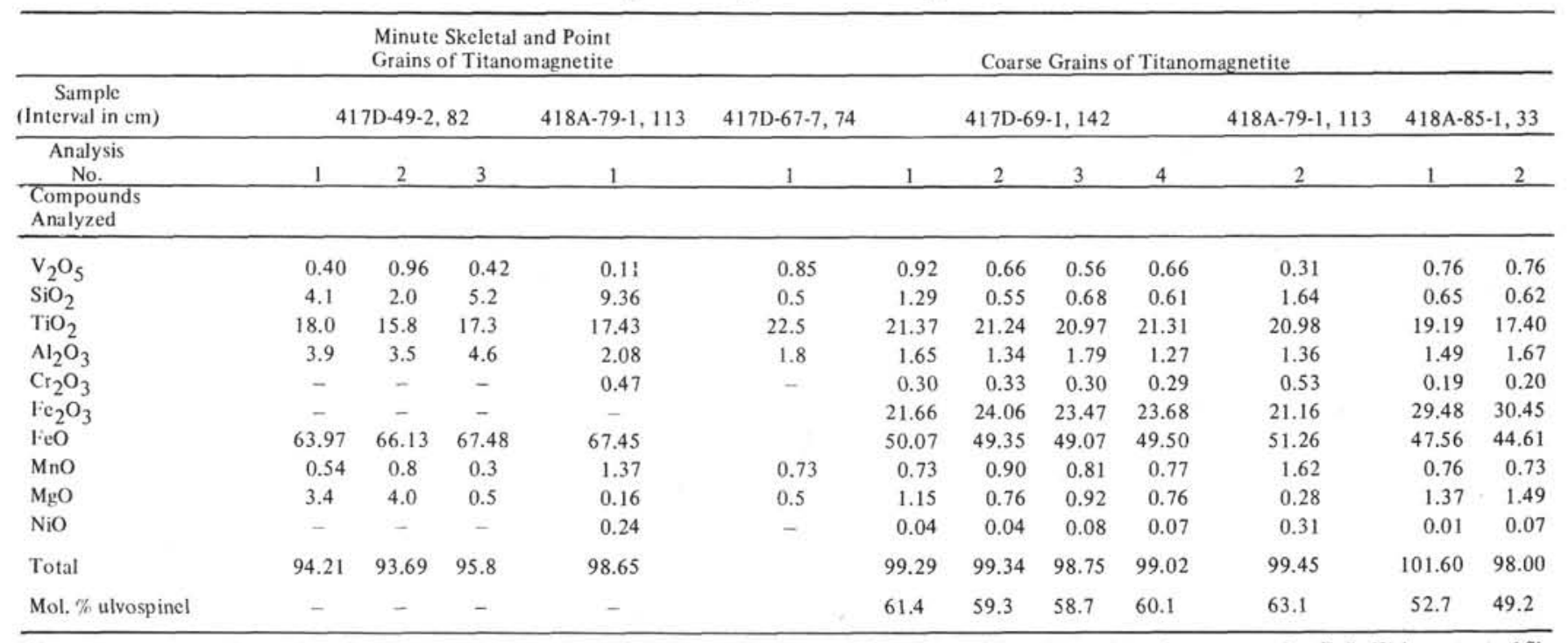

Note: In Analyses 1, 2, and 3 of Sample 417D-49-2, $82 \mathrm{~cm}$ and Analysis 1 of Sample 418A-79-1, 113 cm, the total iron is represented as FeO. High content of Si, $\mathrm{Mg}$, and $\mathrm{Al}$ in these analyses appears related to minute silicate inclusions.

TABLE 3

Microprobe Analyses of Coexisting Titanomagnetites and Ilmenites

\begin{tabular}{|c|c|c|c|c|c|c|}
\hline $\begin{array}{c}\text { Sample } \\
\text { (Interval in } \mathrm{cm} \text { ) }\end{array}$ & \multicolumn{5}{|c|}{$417 \mathrm{D}-69-1,142$} & \multirow{2}{*}{$\begin{array}{c}418 \mathrm{~A}- \\
85-1,33 \\
1 \\
\end{array}$} \\
\hline $\begin{array}{c}\text { Analysis } \\
\text { No. }\end{array}$ & & 1 & & 2 & 3 & \\
\hline \multicolumn{7}{|l|}{$\begin{array}{l}\text { Compounds } \\
\text { Analyzed }\end{array}$} \\
\hline \multicolumn{7}{|l|}{ Titanomagnetite } \\
\hline $\mathrm{v}_{2} \mathrm{O}_{5}$ & & 1.06 & & 0.97 & 1.3 & 1.44 \\
\hline $\mathrm{SiO}_{2}$ & & 0.48 & & 0.71 & 0.39 & 1.05 \\
\hline $\mathrm{TiO}_{2}$ & & 21.6 & & 21.3 & 19.6 & 15.52 \\
\hline $\mathrm{Al}_{2} \mathrm{O}_{3}$ & & 2.4 & & 1.82 & 2.9 & 3.16 \\
\hline $\mathrm{Cr}_{2} \mathrm{O}_{3}$ & & 0.37 & & 0.31 & 0.37 & 0.15 \\
\hline $\mathrm{Fe}_{2} \mathrm{O}_{3}$ & & 17.64 & & 22.17 & 22.43 & 19.56 \\
\hline $\mathrm{FeO}$ & & 53.02 & & 49.57 & 49.78 & 50.85 \\
\hline $\mathrm{MnO}$ & & 0.59 & & 0.75 & 0.45 & 0.56 \\
\hline $\mathrm{MgO}$ & & 1.23 & & 0.92 & 1.5 & 3.13 \\
\hline $\mathrm{NiO}$ & & - & & - & - & 0.08 \\
\hline Total & & 98.39 & & 98.52 & 98.72 & 95.51 \\
\hline Mol. \% ulvospinel & & 64.4 & & 59.5 & 53.6 & 52.0 \\
\hline \multicolumn{7}{|l|}{ Ilmenite } \\
\hline $\mathrm{v}_{2} \mathrm{O}_{5}$ & 0.32 & 0.38 & 0.37 & 0.60 & 0.43 & 0.33 \\
\hline $\mathrm{SiO}_{2}$ & 0.63 & 1.0 & 0.79 & 0.81 & 0.27 & 0.76 \\
\hline $\mathrm{TiO}_{2}$ & 48.22 & 48.03 & 48.14 & 48.5 & 50.3 & 47.88 \\
\hline $\mathrm{Al}_{2} \mathrm{O}_{3}$ & 0.29 & 0.33 & 0.33 & 0.42 & 0.26 & 0.29 \\
\hline $\mathrm{Cr}_{2} \mathrm{O}_{3}$ & 0.35 & 0.33 & 0.33 & 0.35 & 0.35 & 0.11 \\
\hline $\mathrm{Fe}_{2} \mathrm{O}_{3}$ & 7.58 & 8.76 & 8.14 & 6.0 & 4.39 & 8.46 \\
\hline $\mathrm{FeO}$ & 39,01 & 38.29 & 39.08 & 40.9 & 41.74 & 36.35 \\
\hline $\mathrm{MnO}$ & 0.63 & 0.59 & 0.63 & 0.82 & 0.47 & 0.73 \\
\hline $\mathrm{MgO}$ & 2.49 & 3.16 & 2.53 & 1.56 & 1.69 & 3.82 \\
\hline $\mathrm{NiO}$ & 0.06 & 0.04 & 0.10 & - & - & 0.04 \\
\hline Total & 99.58 & 101.02 & 100.54 & 99.96 & 99.96 & 98.79 \\
\hline Mol. $\% \mathrm{R}_{2} \mathrm{O}_{3}$ & 8.1 & 8.9 & 8.7 & 7.1 & 5.2 & 8.7 \\
\hline $\mathrm{T}^{\circ} \mathrm{C}^{\mathrm{a}}$ & & 1050 & & 960 & 920 & 940 \\
\hline $\log f \mathrm{O}_{2} \mathrm{a}$ & & -11.0 & & -11.8 & -12.4 & -12.2 \\
\hline $\mathrm{T}^{\circ} \mathrm{C}^{\mathrm{b}}$ & & 1100 & & 1035 & 980 & 1030 \\
\hline $\log f \mathrm{O}_{2}^{\mathrm{b}}$ & & -10.0 & & -10.4 & -11.8 & -11.8 \\
\hline
\end{tabular}

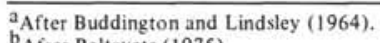

$b_{\text {Afrer Poltavets (1975). }}$ ure 4) indicates that their formation was later than the crystallization of larger magnetite grains and that the temperature of fine-grained skeletal magnetite crystallization was equal to exsolution temperature of the coarse magnetite grains.

\section{Chromite}

Chromium spinel is not a rare mineral of the basalts discussed; rather, it is abundant, especially in Unit $6 \mathrm{~b}$ of Hole 418A (see Site 418 Report, this volume). It occurs there not only as minute inclusions, but also as rare small phenocrysts. However, in the specimens studied here (Table 1), we found it only in the coarse-grained aphyric basalt (Sample $418 \mathrm{~A}-85-1,33 \mathrm{~cm}$ ). There were only five minute spinel grains in the entire polished section, and all were located in two neighboring, partly altered olivine phenocrysts (Plate 3, Figure 4). The spinel grains are included in smectite pseudomorphs after olivine and have different shapes and sizes. One of them (Plate 3, Figure 4, Grain 1) is angular with dimensions of 50 by $100 \mu \mathrm{m}$. The other spinel grains are rounded and about $40 \mu \mathrm{m}$ across; some include very fine, rounded silicate grains.

Microprobe analyses of four of the spinel grains (Table 4) have demonstrated significant differences in their composition. Three types can be distinguished by $\mathrm{Fe}-\mathrm{Al}-\mathrm{Mg}$ relations. The first type (identified as Grain 1) has high $\mathrm{FeO}+$ $\mathrm{Fe}_{2} \mathrm{O}_{3}$ and low $\mathrm{Al}_{2} \mathrm{O}_{3}$ and $\mathrm{MgO}$ contents. Another type is noted for low iron and high alumina and magnesia contents (Grain 4). The third type is intermediate (Grains 2 and 3). We found no composition zonality in the grains, as opposed to the zonal spinels from basalts and peridotites recovered in Leg 37 (Sigurdsson, 1977).

Chemical distinctions of the neighboring spinel grains indicate that there was a time sequence in their crystalliza- 
TABLE 4

Microprobe Analyses of Chromospinels From Sample 418A-85-1, $33 \mathrm{~cm}$

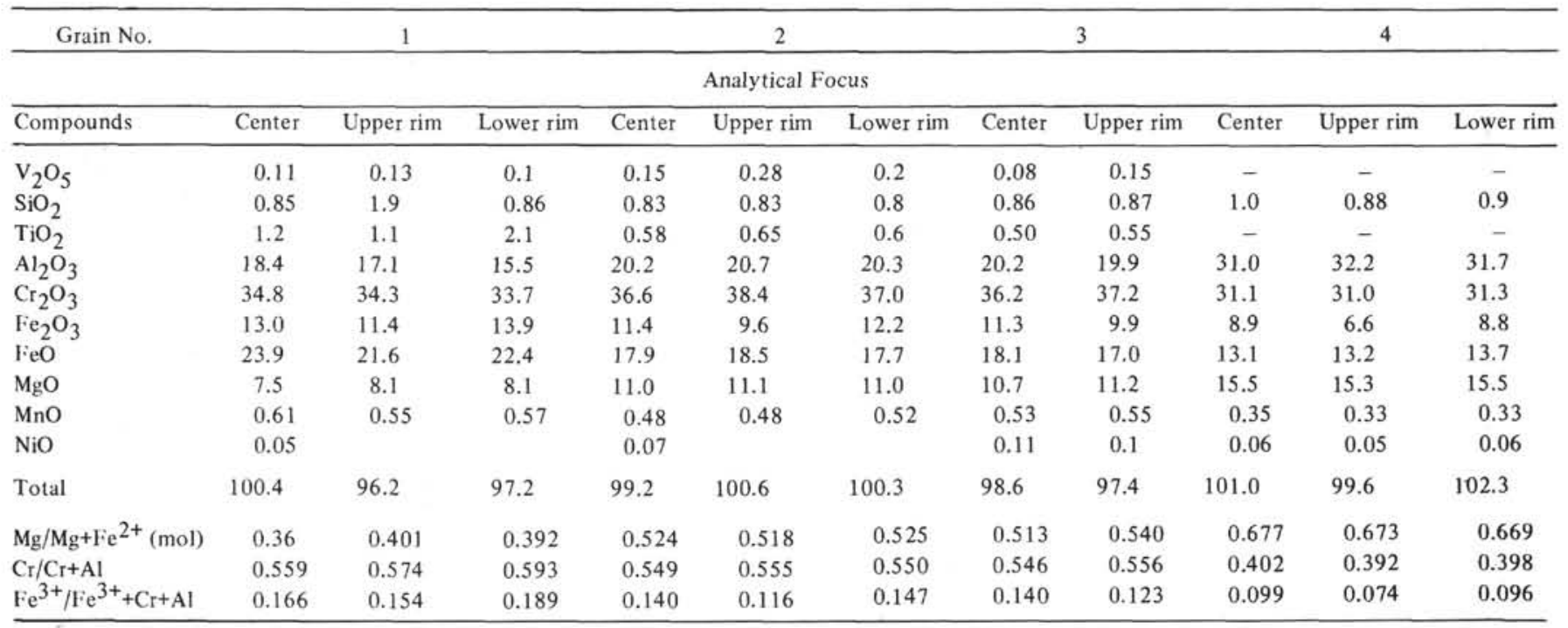

tion. The angular chromite grains seem to be formed later than the others, at increasing oxygen fugacity in the melt. However, the data are insufficient for well-founded conclusions.

Comparison between spinel compositions determined here and spinels of MAR basalts, gabbros, and peridotites (Sigurdsson, 1977; Clarke and Loubat, 1977; Symes et al., 1977 ) is given in the $\mathrm{Fe}^{3+} / \mathrm{Fe}^{3+}+\mathrm{Cr}+\mathrm{Al}$ versus $\mathrm{Mg} / \mathrm{Mg}$ $+\mathrm{Fe}^{2+}$ diagram (Figure 1). Significant differences between them are accountable by the fact that the composition field of the spinels from lavas and peridotites of Leg 37 is within the spinel field from alpine peridotites, while only Grain 4 from Sample 418A-85-1, $33 \mathrm{~cm}$ is within the spinel field. Compositions of Grains 2 and 3 are in the spinel field from Bushveld and Stillwater stratiform intrusives. Compositions of Grain 1 are outside even the last field. $\mathrm{Mg} / \mathrm{Mg}$ $+\mathrm{Fe}^{2+}$ values in olivines of Sample $418 \mathrm{~A}-85-1,33 \mathrm{~cm}$ vary from 0.83 to 0.89 . Our olivine-chromite pairs fell within the Stillwater field in the $\mathrm{Fe}^{2+}$ versus $\mathrm{Mg}$ distribution diagram (Sigurdsson, 1977) distal from the MAR basalts field.

\section{Sulfides}

Primary sulfide aggregates consisting mainly of pyrrhotite with subordinate chalcopyrite, cubanite, and minor to rare pentlandite occur almost exclusively in fresher coarsegrained basalts (Samples 417D-69-1, $142 \mathrm{~cm}$ and 418A$85-1,33 \mathrm{~cm})$. It is important to note the following features of these sulfides.

1) Globular or ellipsoidal forms, from 10 to $100 \mu \mathrm{m}$ across, are very characteristic (Plate 4 , Figures 1 and 2).

2) Sulfide globules are found predominately in finegrained interstitial mesostasis located between coarse grains of plagioclase, clinopyroxene, and olivine (Plate 4, Figure 1).

3) Primary sulfide aggregates are subordinate to titanomagnetite aggregates (Plate 4, Figure 3). There are semispheric growths of sulfides on titanomagnetite grains (Plate

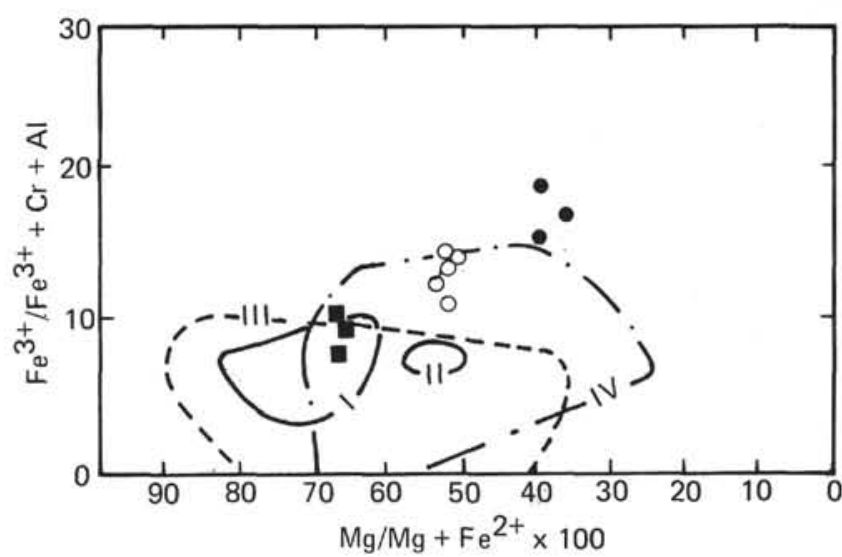

Figure 1. Diagram of $\mathrm{Mg} / \mathrm{Mg}+\mathrm{Fe}^{2+}$ versus $\mathrm{Fe}^{3} / \mathrm{Fe}^{3+}+\mathrm{Al}+\mathrm{Cr}$ for chromites from Sample 418A-85-1, $33 \mathrm{~cm}$ and other chromite mineralization occurrences. The compositions of chromites from Sample 418A-85-1 (Table 4): filled circles $=$ grain $1 ;$ open circles $=$ grains 2 and $3 ;$ filled squares $=$ grain 4 . The composition fields of spinels: I - from Leg 37 basalts (Sigurdsson, 1977), II - from Leg 37 peridotites (Sigurdsson, 1977), III - from alpine peridotites (Irvine, 1967), IV - from the Stillwater and Bushveld layered igneous complexes (Irvine, 1967).

4, Figure 4), indicating later formation of sulfides in comparison with coarse magnetite grains.

4) Sulfide aggregates contain minute inclusions of basalt glass.

5) Sulfide aggregates occur as intergrowths of different sulfide minerals and as homogeneous masses.

In addition to the sulfides found in Samples 417D-69-1, $142 \mathrm{~cm}$ and $418 \mathrm{~A}-85-1,33 \mathrm{~cm}$, primary sulfides have been found as minute spherical pyrrhotite and pyrrhotitechalcopyrite inclusions in plagioclase phenocrysts (Samples 417D-67-7, $74 \mathrm{~cm}$; 418A-57-4, $136 \mathrm{~cm}$; and 418A-79-6, 60 $\mathrm{cm})$. Primary sulfides in the studied samples of basalts with 
fine-grained groundmass are usually absent, unlike the widespread distribution of sulfide globules in the Leg 37 basalts (Hall and Fisher, 1977). This scarcity seems to be connected with the more intensive alteration of the Leg 51-53 fine-grained basalts.

\section{Pyrrhotite}

The mineral is distributed mostly in homogeneous globules. Some of them contain very small flame-like or lamellar inclusions of pentlandite seen only at great magnifications (Plate 4, Figure 2). Pyrrhotite-chalcopyrite intergrowths also occur. Chalcopyrite usually forms rims around pyrrhotite globules, but sometimes is the predominant phase with small inclusions of pyrrhotite.

The compositions of the pyrrhotite grains are notable for their high sulfur contents and rather low concentrations, up to 0.1 per cent of copper and up to 0.6 per cent of nickel (Table 5). High sulfur contents are borne out by X-ray powder diagrams which give a very small values for the $d_{102}$ reflections $(2.060 \AA)$. The pyrrhotite grains display monoclinic symmetry that was initially confirmed by magnetic suspension.

\section{Chalcopyrite}

This mineral occurs much less frequently than pyrrhotite. It occurs in intergrowth with pyrrhotite or in homogeneous grains. The homogeneous grains are sometimes euhedral, as opposed to pyrrhotite, and contain very small inclusions of a silicate mineral. Unlike pyrrhotite, the chalcopyrite varies significantly in composition (Table 5). Chalcopyrite from intergrowths with pyrrhotite has a constant composition similar to most common chalcopyrite. Copper content in it is not less than 31 per cent (recalculated to $100 \%$ ); nickel concentration does not exceed 1 per cent, and its iron content is rather high, 32 to 33 per cent.

A second, rarer group of $\mathrm{Cu}$-Fe-sulfides was discovered during microprobe investigations. Their composition is similar to cubanite. Results of the analyses of three cubanite grains (Table 5, Analyses 21 to 25) indicate much higher $\mathrm{Ni}$-content than in chalcopyrite. Two of the cubanite grains have compositional homogeneity (Analyses 21 and 25), while the third is rather variable (Analyses 22 to 24). High copper ( 15.5 to $25.2 \%$ ) and nickel (6.4 to $12.5 \%$ ) content is found in a grain of Cu-Ni-sulfide in Sample 417D-69-1, 142 $\mathrm{cm}$ (Table 5, Analyses 12 to 15). These compositions appear to be $\mathrm{Ni}$-rich intermediate solid solutions.

\section{Pentlandite}

The mineral forms very small $(\sim 1 \mu \mathrm{m})$, flame-like lamellar inclusions in pyrrhotite grains (Plate 4, Figure 2). We were unable to conduct microprobe analyses of pentlandite because of its small size, but the diagnosis is fully predictable. Some globules contain all three sulfide minerals: pyrrhotite, calcopyrite, and pentlandite.

Compositions of primary sulfides from oceanic basalts have significant differences according to various researchers (e.g., Czamanske and Moore, 1977; MacLean, 1977a, b). Distinctions in iron sulfide compositions are especially notable. Basaltic glass from the FAMOUS area contains monosulfide solid solution minerals (Czamanske and Moore, 1977) with low sulfur content (36 to 37\%), and high
TABLE 5

Microprobe Analyses of Magmatic Sulfides

\begin{tabular}{|c|c|c|c|c|c|c|c|}
\hline $\begin{array}{c}\text { Sample } \\
\text { (Interval in } \mathrm{cm} \text { ) }\end{array}$ & $\begin{array}{c}\text { Analyses } \\
\text { No. }\end{array}$ & Mineral $^{\mathrm{a}}$ & $\mathrm{Fe}$ & $\mathrm{Cu}$ & $\mathrm{Ni}$ & S & Total \\
\hline \multirow{15}{*}{$417 \mathrm{D}-69-1,142$} & 1 & Po -1 & 57.3 & 0.14 & 0.61 & 39.0 & 97.05 \\
\hline & 2 & $\mathrm{Cp}-1$ & 29.0 & 30.4 & 0.88 & 32.0 & 92.37 \\
\hline & 3 & Po -2 & 57.7 & 0.08 & 0.63 & 39.0 & 97.4 \\
\hline & 4 & $\mathrm{Cp}-2$ & 30.3 & 32.4 & 0.85 & 34.2 & 97.84 \\
\hline & 5 & $\mathrm{Po}-3$ & 58.1 & - & 0.6 & 39.1 & 97.8 \\
\hline & 6 & $\mathrm{Cp}-3$ & 30.9 & 32.0 & 0.8 & 33.6 & 97.4 \\
\hline & 7 & Po $=4$ & 60.0 & - & 0.1 & 40.6 & 100.7 \\
\hline & 8 & $C p-4$ & 31.7 & 30.5 & 6.61 & 36.3 & 99.11 \\
\hline & 9 & Po -5 & 59.9 & - & 0.11 & 40.2 & 100.2 \\
\hline & 10 & $C p=5$ & 31.1 & 32.2 & 1.0 & 34.6 & 98.9 \\
\hline & 11 & Po -6 & 60.3 & - & 0.23 & 40.0 & 100.5 \\
\hline & 12 & Iss -7 & 31.6 & 25.2 & 6.4 & 36.0 & 99.2 \\
\hline & 13 & Iss -7 & 30.7 & 23.9 & 7.9 & 34.4 & 96.8 \\
\hline & 14 & Iss - 7 & 37.9 & 15.5 & 9.5 & 36.2 & 99.1 \\
\hline & 15 & Iss - 7 & 30.2 & 17.0 & 12.5 & 34.5 & 94.2 \\
\hline \multirow{10}{*}{$418 \mathrm{~A}-85-1,33$} & 16 & Po -1 & 58.1 & 0.06 & 0.3 & 39.8 & 98.2 \\
\hline & 17 & Po -2 & 58.0 & 0.16 & 0.4 & 39.7 & 98.1 \\
\hline & 18 & $\mathrm{Cp}-2$ & 31.6 & 31.8 & 0.85 & 35.2 & 99.45 \\
\hline & 19 & $\mathrm{Cp}-3$ & 32.8 & 30.7 & 0.9 & 35.8 & 99.7 \\
\hline & 20 & $C p-4$ & 32.6 & 30.3 & 0.83 & 34.4 & 98.1 \\
\hline & 21 & $\mathrm{Cb}-5$ & 37.3 & 23.0 & 2.6 & 36.6 & 99.5 \\
\hline & 22 & $\mathrm{Cb}-6$ & 37.0 & 24.2 & 3.3 & 36.1 & 100.6 \\
\hline & 23 & $\mathrm{Cb}-6$ & 34.1 & 27.5 & 2.0 & 36.1 & 99.7 \\
\hline & 24 & $\mathrm{Cb}-6$ & 38.7 & 20.1 & 4.2 & 36.6 & 99.6 \\
\hline & 25 & $\mathrm{Cb}-7$ & 41.4 & 20.8 & 2.0 & 35.4 & 99.6 \\
\hline
\end{tabular}

${ }^{\text {a }}$ Po $=$ pyrrhotite, $\mathrm{Cp}=$ chalcopyrite, Iss $=$ intermediate solid solution, and $\mathrm{Cb}=$ cubanite; the numerals with the mineral symbols are identification numbers of analyzed grains consisting of either homogeneous minerals or sulfide intergrowths.

$\mathrm{Ni}(3.4$ to $17.1 \%)$ and $\mathrm{Cu}(0.55$ to $2.73 \%)$. Mathez (1976) has described similar monosulfide solid solution minerals from Pacific basalt glass. Pyrrhotite with high sulfur content (not less than $39 \%)$, and low $\mathrm{Ni}(0$ to $1.5 \%)$ and $\mathrm{Cu}(0$ to $0.2 \%$ ), occurs in glass and fine-grained basalts of Leg 37 (MacLean, 1977a, b). There are also differences in $\mathrm{Cu}-\mathrm{Fe}$-sulfides. FAMOUS basalts contain intermediate solid solution minerals with 20 to 33 per cent $\mathrm{Cu}, 33$ to 43 per cent $\mathrm{Fe}$, and 0.9 to 2.3 per cent $\mathrm{Ni}$, while MAR basalts of Leg 37 have variable intermediate solid solution minerals side-by-side with chalcopyrite with low Ni-content. The main reason for all these differences, evidently, is variation in rates of basalt solidification. Sulfides of coarse-grained basalts from Holes 417D and 418A are most similar to sulfides of Leg 37 basalts which crystallized at rather slow cooling rates. Re-equilibration could occur under subsolidus conditions causing intermediate and monosulfide solid solution minerals to be converted into pyrrhotite and chalcopyrite aggregates.

\section{SECONDARY OPAQUE MINERALS}

\section{Pyrite}

This, the most widespread of all sulfide minerals, develops with other alteration products in basalts. Pyrite forms predominantly homogeneous grains or aggregates, but locally occurs with marcasite and chalcopyrite in intergrowths. One can observe it in fine-grained basalt groundmass as small irregular distributed aggregates or, less frequently, as rather coarse grains (Plate 5, Figure 1) up to 1 $\mathrm{mm}$ across. Fine pyrite veinlets cut the groundmass and plagioclase or pyroxene phenocrysts (Plate 5, Figure 2). Its vesicle rims, filled with calcite (Plate 5, Figure 3) or smectite, are characteristic. Pyrite also replaces quartz in vesicles filled with calcite and surrounded with quartz rims (Plate 5, Figure 4). The mineral seems to be one of the latest 
hydrothermal alteration products and is a common product of halmyrolysis. Compositions of studied pyrites are similar to the pyrites described by MacLean (1977) from MAR basalts of Leg 37 . The principal minor elements are $\mathrm{Ni}$ and Co (usual 0.03 to $0.1 \%$ ). Uneven distribution of these elements is peculiar. Pyrite rims (Plate 5, Figure 3), for example, have a zonality in $\mathrm{Ni}$ and Co contents as is demonstrated by X-ray scans (Plate 6, Figure 1a, b). Concentrations of $\mathrm{Ni}$ and $\mathrm{Co}$ in some places reach 0.53 and 0.43 per cent, respectively.

\section{Marcasite}

The mineral occurs much less often than pyrite, and forms growths with it. These growths are composed of minute grain aggregates. The grain texture of marcasite is demonstrated at crossed nicols due to anisotropy of the mineral.

\section{Chalcopyrite}

Secondary chalcopyrite occurs in altered basalts in close assemblages with pyrite, but in lesser quantities. It forms locally minute inclusions and growths with pyrite in basalt groundmass. Rare, larger aggregates of pyrite and chalcopyrite replace silicate minerals giving pseudomorphs (Plate 6, Figure 2). Chalcopyrite also occurs in thin rims around vesicles with calcite fillings (Plate 6, Figure 3). Dimensions of separate chalcopyrite grains reach to 100 to $150 \mu \mathrm{m}$ (Plate 6 , Figure 4a). They usually contain abundant minute inclusions of secondary silicates which cause microprobe analyses totals to be low. For example, analysis of the grain shown in Plate 6, Figure 4a, provides the following results: $\mathrm{Cu}=32.6, \mathrm{Fe}=29.4, \mathrm{Ni}=0.06, \mathrm{Co}=0.03$, and $\mathrm{S}=33.5$, for a total of 95.59 per cent. X-ray scans of the same grain (Plate 6, Figures $4 \mathrm{~b}, \mathrm{c}$ ) demonstrate nickelenrichment in its periphery similar to the pyrite grains. This enrichment seems to be caused by nickel extraction from rock-forming silicates during their interaction with solutions during alteration.

\section{Iron Hydroxides}

Found in Sample 417D-49-2, $82 \mathrm{~cm}$, iron hydroxide aggregates are located in a celadonite veinlet as a chain of grains (Plate 7, Figure 1). In addition, they form pseudomorphs after parts of celadonite grains in basalt groundmass (Plate 7, Figure 2). Composition of the hydroxide from the veinlet is similar to the mineral composition from the groundmass (Table 6). Both analyses demonstrate a notable admixture of silica.

\section{CONCLUSIONS}

1. We have studied opaque minerals in 27 specimens of basalts recovered in Holes 417D and 418A. The most widespread primary ore mineral is titanomagnetite. There are also ilmenite, chromite, and sulfide globules occurring

TABLE 6

Microprobe Analyses of Iron Hydroxides

\begin{tabular}{lcccccccc}
\hline & $\mathrm{Fe}_{2} \mathrm{O}_{3}$ & $\mathrm{~V}_{2} \mathrm{O}_{5}$ & $\mathrm{Al}_{2} \mathrm{O}_{3}$ & $\mathrm{MgO}$ & $\mathrm{MnO}$ & $\mathrm{CaO}$ & $\mathrm{SiO}_{2}$ & Total \\
\hline Veinlets & 76.3 & 0.11 & 0.89 & 1.0 & 0.09 & 0.33 & 7.3 & 86.02 \\
Groundmass & 75.4 & 0.18 & 0.83 & 1.0 & 0.08 & 0.49 & 6.5 & 84.38 \\
\hline
\end{tabular}

in coarse-grained basalts. The predominant secondary opaque mineral is pyrite, which is accompanied sometimes by growths of chalcopyrite and marcasite. Iron hydroxides are also found.

2. Microprobe analyses of coexisting titanomagnetites and ilmenites indicate that the temperatures of formation and re-equilibration of these minerals lie between $1100^{\circ}$ and $980^{\circ} \mathrm{C}$.

3. Chromites found in a sample of coarse-grained basalt are highly variable in composition, even in adjacent grains. They are noted for higher $\mathrm{Fe}^{3+} / \mathrm{Fe}^{3+}+\mathrm{Al}+\mathrm{Cr}$ and lower $\mathrm{Mg} / \mathrm{Mg}+\mathrm{Fe}^{2+}$ values, than $\mathrm{Cr}$-spinels of the Leg 37 MAR basalts.

4. Compositions of the sulfide globules (consisting of monoclinic pyrrhotite, chalcopyrite, cubanite, and pentlandite) alongside coexisting titanomagnetite-ilmenite intergrowths and are indicative of rather slow cooling of the coarse-grained basalts containing them. Subsolidus conversions and re-equilibration-inducing exsolution of monosulfide and intermediate solid solution minerals and titanomagnetite took place in the rocks.

5. The latest hydrothermal and halmyrolysis alterations, performed intensively (especially in basalts with finegrained groundmass), lead to formation of widespread pyrite mineralization.

\section{REFERENCES}

Buddington, A.F. and Lindsley, D.H., 1964. Iron-titanium oxide minerals and synthetic equivalents, J. Petrol., v. 5, p. 310375.

Carmichael, C.M., 1970. The Mid-Atlantic Ridge near $45^{\circ}$ N. VII. Magnetic properties and opaque mineralogy of dredged samples, Canadian J. Earth Sci., v. 7, p. 239-256.

Carmichael, I.S.E., 1967. The iron-titanium oxides of salic volcanic rocks and their associated ferromagnesian silicates, Contrib. Mineral. Petrol., v. 14, p. 36-64.

Clarke, D.B. and Loubat, H., 1977. Mineral analysis from the peridotite-gabbro-basalt complex at Site 334, DSDP Leg 37. In Aumento, F., Melson, W.G., et al., Initial Reports of the Deep Sea Drilling Project, v. 37: Washington (U.S. Government Printing Office), p. 841-856.

Czamanske, G.K. and Moore, J.G., 1977. Composition and chemistry of sulfide globules in basalt from the Mid-Atlantic Ridge rift valley near $37^{\circ} \mathrm{N}$ latitude, Geol. Soc. Am. Bull., v. 88 , no. 4 , p. $587-599$.

Hall, J.M. and Fisher, J.F., 1977. Opaque mineralogy of basement rocks, Leg 37. In Aumento, F., Melson, W.G., et al., Initial Reports of the Deep Sea Drilling Project, v. 37: Washington (U.S. Government Printing Office), p. 857-874.

Irvine, T.N., 1967. Chromian spinel as a petrogenetic indicator. Part 2. Petrologic applications, Canadian J. Earth Sci., v. 4, p. $71-103$

MacLean, W.H., 1977a. Sulfides in Leg 37 drill core from the Mid-Atlantic Ridge. Canadian J. Earth Sci., v. 14, p. 656683.

1977b. Sulfides in the core from Leg 37 drill holes. In Aumento, F., Melson, W.G., et al., Initial Reports of the Deep Sea Drilling Project, v. 37: Washington (U.S. Government Printing Office), p. 875-882.

Mathez, E.A., 1976. Sulfur solubility and magmatic sulfides in submarine basalt glass, J. Geophys. Res., v. 81, p. 4269-4276.

Poltavets, J.A., 1975. The discussion of Buddington-Lindsley titanomagnetite geothermometre on the basis of comparative analysis of the equilibrium of magnetite serie spinels, Izvestia of the USSR Acad. of Sci., ser. geol., p. 63-72. 
Sigurdsson, H., 1977. Spinels in Leg 37 basalts and peridotites: phase chemistry and zoning. In Aumento, F., Melson, W.G., et al., Initial Reports of the Deep Sea Drilling Project, v. 37: Washington (U.S. Government Printing Office), p. 883-892.

Symes, R.F. and Bevan, J.C., Hutchison, R., 1977. Phase chemistry studies on gabbro and peridotite rocks from Site 334,
DSDP Leg 37. In Aumento, F., Melson, W.G., et al., Initial Reports of the Deep Sea Drilling Project, v. 37: Washington (U.S. Government Printing Office), p. 841-846.

Wayman, M.L., and Evans, M.E., 1977. Oxide microstructures and the magnetic properties of Leg 37 basalts, Canadian J. Earth Sci., v. 14, p. 656-663. 
PLATE 1

Figure 1 Minute skeletal grains of titanomagnetite (white). Sample 417D-49-2, $82 \mathrm{~cm}$.

Figure 2 Dendritic-skeletal form of a coarser grain and minute point grains of titanomagnetite. Sample 417D-49-2, $82 \mathrm{~cm}$.

Figure 3 Minute point grains of titanomagnetite in mesostasis of coarse-grained basalt. Sample 418A-79-1, $113 \mathrm{~cm}$.

Figure $4 \quad$ Forms of minute titanomagnetite grains in mesostasis of coarse-grained basalt. Sample 418A-79-1, $113 \mathrm{~cm}$. 
PLATE
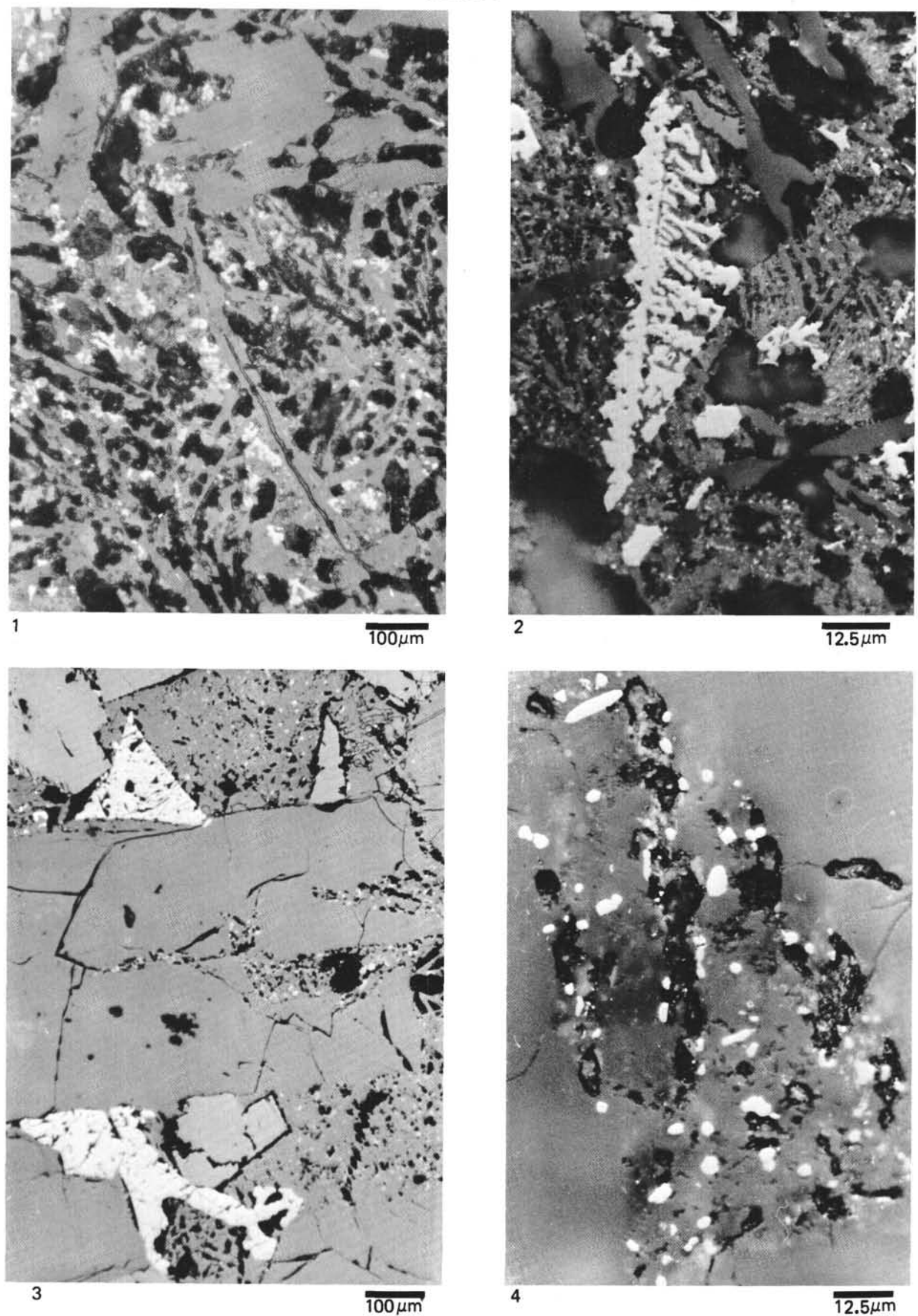


\section{PLATE 2}

Figure 1

Figure 2

Figure 3
X-ray scans of $\mathrm{Ti}_{\alpha_{1}}$ (a) and $\mathrm{Fe}_{\alpha_{1}}$ (b) showing the distribution of titanomagnetite around a vesicle. $150 \times, 150 \mu \mathrm{m}$. Sample 417D-59-3, $104 \mathrm{~cm}$.

Coarse grains of titanomagnetite (white) and small sulfide globules in coarse-grained basalt. Sample 418 A-79-6, $60 \mathrm{~cm}$.

A big skeletal titanomagnetite grain (white) in mesostasis of coarse-grained basalt. Sample 417D-69-1, $142 \mathrm{~cm}$.

A skeletal titanomagnetite grain (white) with minute sulfide globules adhered to it. Sample 417D-69-1, $142 \mathrm{~cm}$. 
PLATE 2
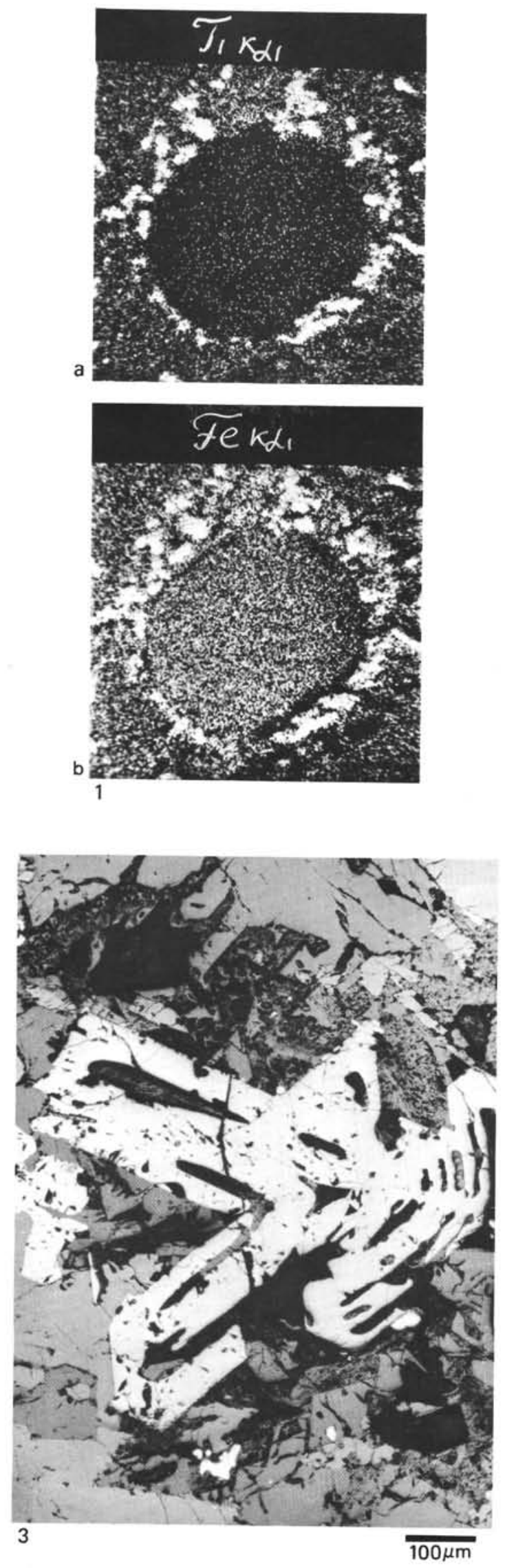
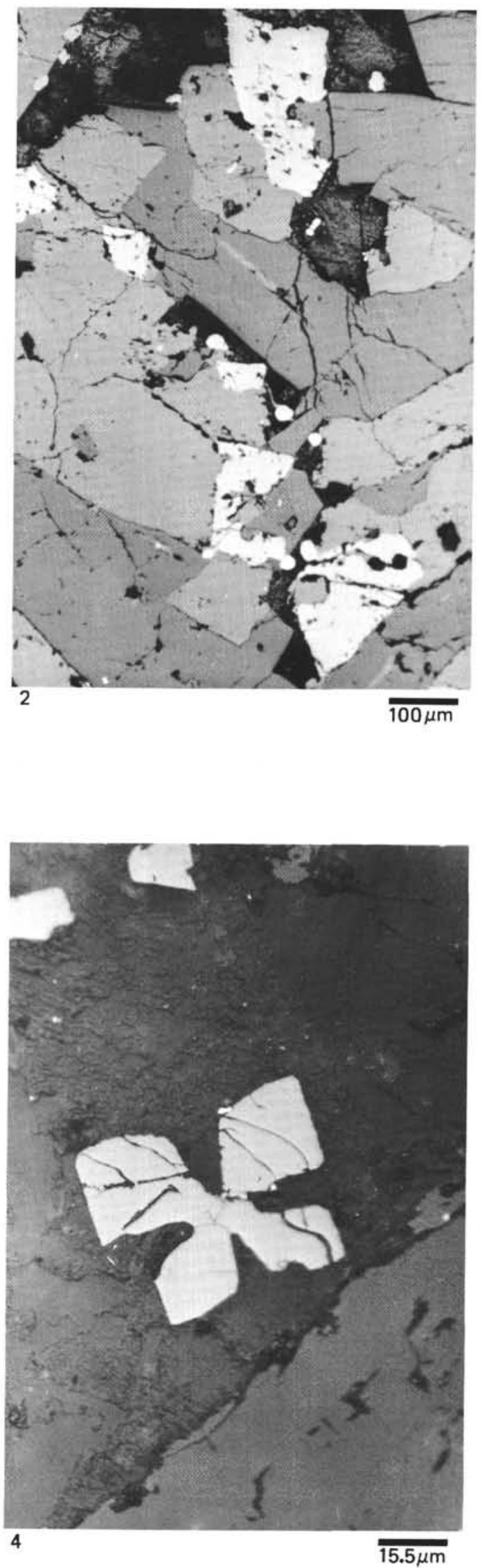


\section{PLATE 3}

Figure 1 Ilmenite lamellae (white) in the grain of titanomagnetite (gray). Sample 417D-69-1, $142 \mathrm{~cm}$.

Figure 2 A big ilmenite lamella (white) in titanomagnetite (gray). Sample 418A-85-1, $33 \mathrm{~cm}$.

Figure 3 Thin ilmenite lamellae (white) in titanomagnetite. Sample 418A-85-1, $33 \mathrm{~cm}$.

Figure 4 Chromospinel grains in smectite $(\mathrm{Sm})$, replacing olivine (Ol). Spinel grains listed in Table 4 are marked with arabic numerals. Sample 418A-85-1, $33 \mathrm{~cm}$. 


\section{PLATE 3}
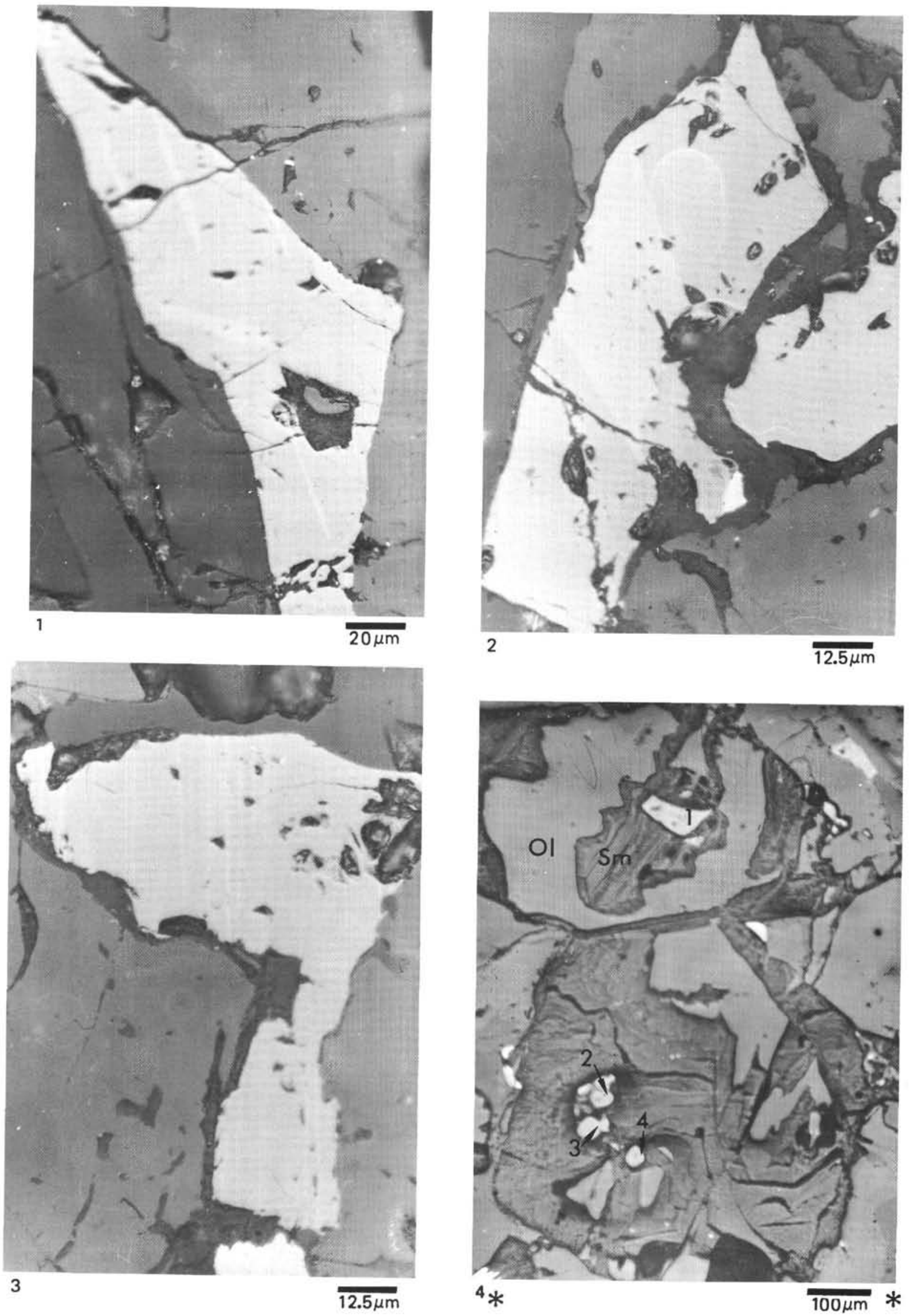


\section{PLATE 4}

Figure 1 Pyrrhotite globules and a large titanomagnetite grain. Sample 417D-69-1, $142 \mathrm{~cm}$.

Figure 2 An ellipsoidal grain of pyrrhotite with flame-like and lamellar inclusions of pentlandite. Sample 418A-85$1,33 \mathrm{~cm}$.

Figure 3 Pyrrhotite (white) with glass inclusions overgrowing a grain of titanomagnetite (gray). Sample 417D-69-1, $142 \mathrm{~cm}$.

Figure 4 An overgrowth of pyrrhotite (white) and titanomagnetite with ilmenite lamellae. Sample 418A-85-1, $33 \mathrm{~cm}$. 
PLATE 4
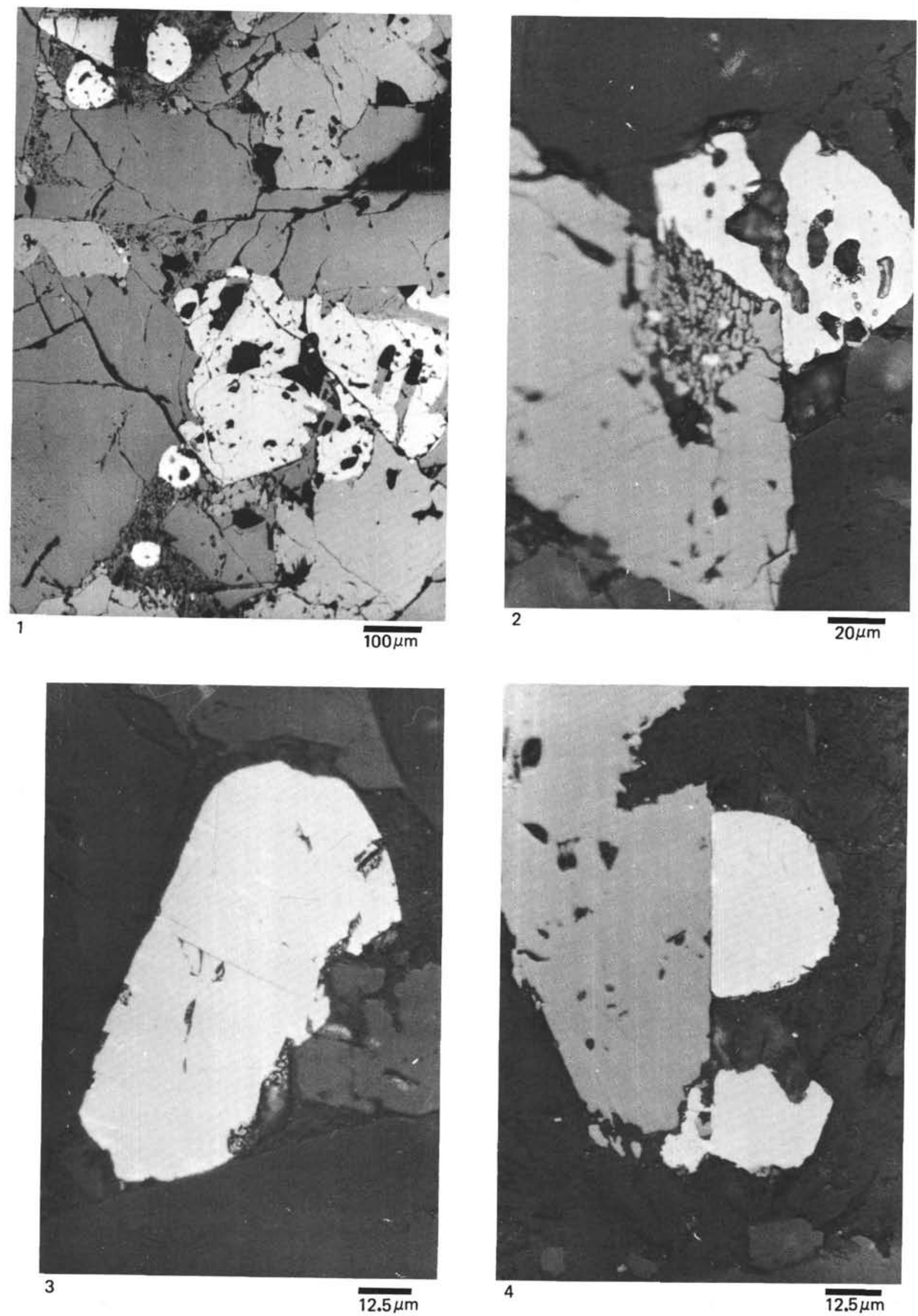


\section{PLATE 5}

Figure 1 Pyrite (white) in basalt. Sample 417D-52-4, $13 \mathrm{~cm}$.

Figure 2 Pyrite veinlets (white) in basalt. Sample 417D-59-3, $104 \mathrm{~cm}$.

Figure 3 A pyrite rim (white) around a carbonate-filled vesicle in basalt. Sample 417D-52-4, $13 \mathrm{~cm}$.

Figure 4 Pyrite (white) replacing a quartz rim around a calcitefilled vesicle in basalt. Sample 418A-58-4, $143 \mathrm{~cm}$. 
PLATE 5
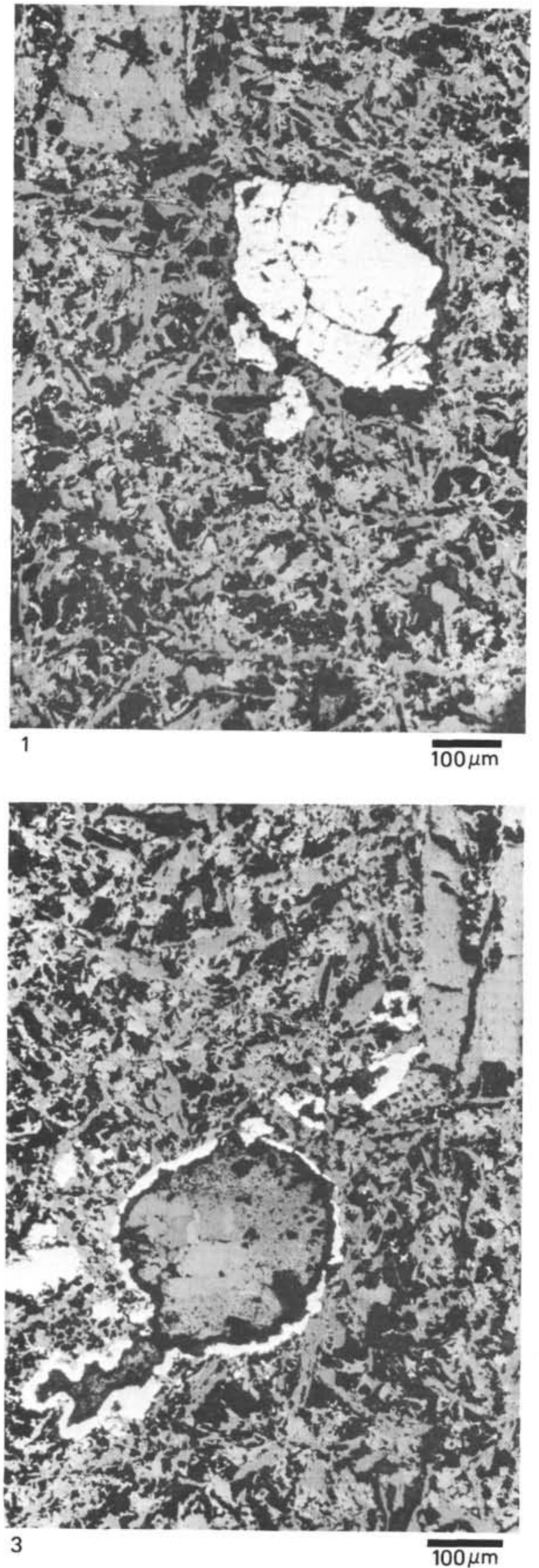
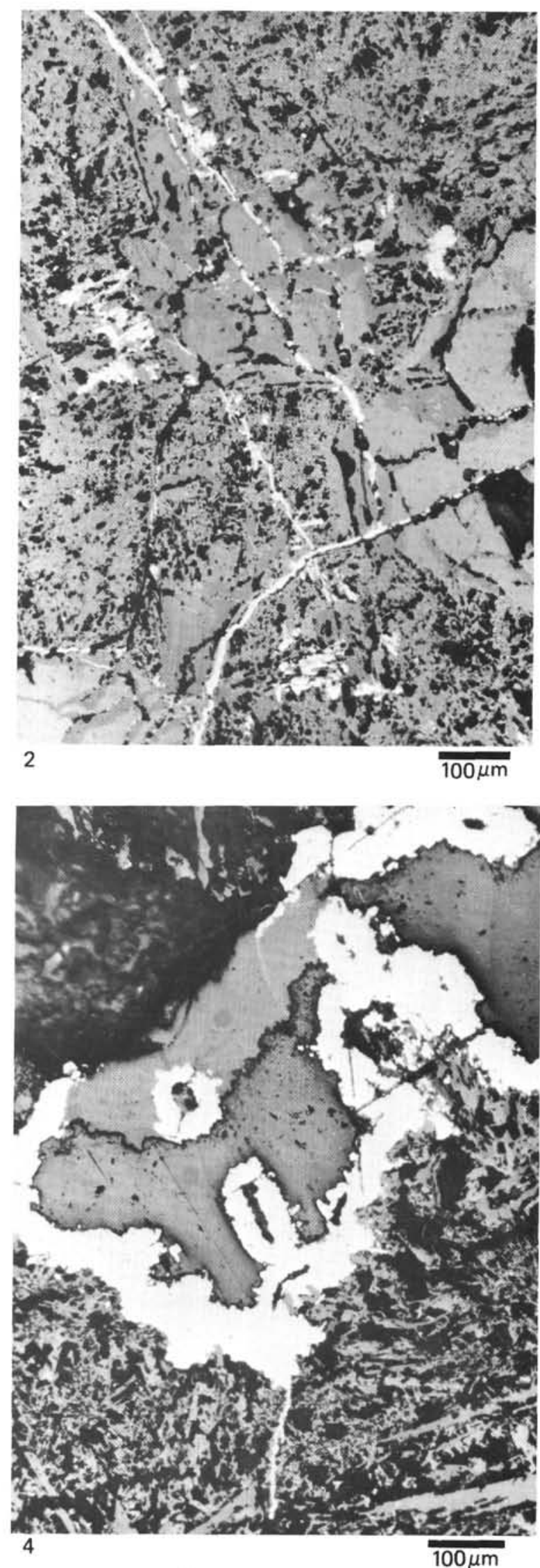
A. D. GENKIN, I. P. LAPUTINA, N. N. PERTSEV

\section{PLATE 6}

Figure $1 \quad \mathrm{X}$-ray scans of the pyrite rim shown in lower left-hand corner of Plate 5, Figure 3; $a=$ NiK $\alpha ; b=$ CoK $\alpha .250 \times$, $250 \mu \mathrm{m}$. Sample 417D-52-4, $13 \mathrm{~cm}$.

Figure 2 Intergrowths of chalcopyrite (1) and pyrite (2) in basalt. Sample 417D-59-3, $104 \mathrm{~cm}$.

Figure 3 A chalcopyrite rim (white) around a smectite-filled vesicle. Sample 417D-59-3, $104 \mathrm{~cm}$.

Figure 4 A chalcopyrite grain (white) (a) and its X-ray scans, (b) $\mathrm{NiK}_{\alpha_{1}}$ and (c) $\mathrm{CoK}_{\alpha_{1}}, 100 \times, 100 \mu \mathrm{m}$. Samples 417D-69-1, $142 \mathrm{~cm}$. 
PLATE 6

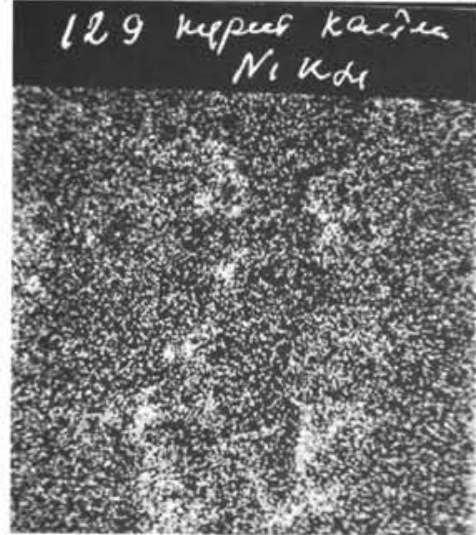

$1 \mathrm{a}$
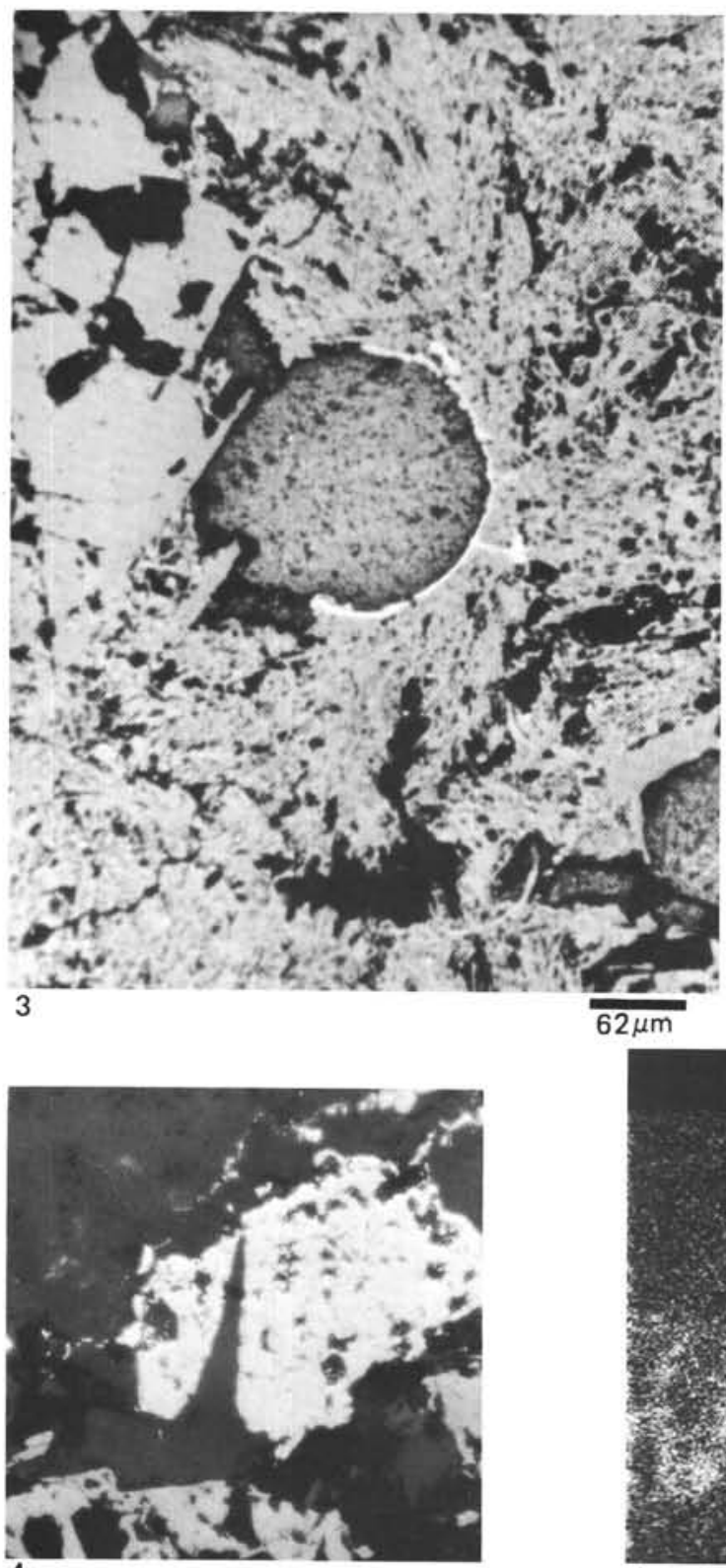

$4 a$

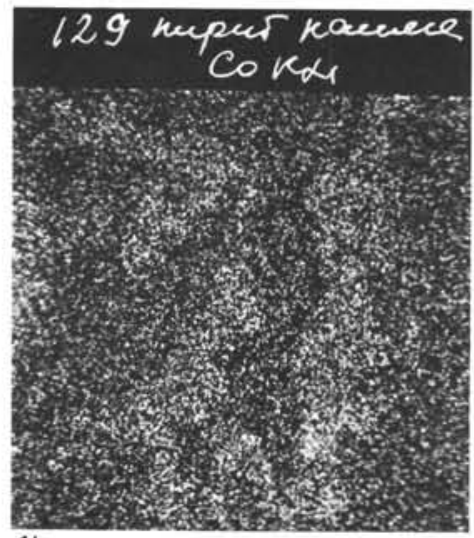

$1 \mathrm{~b}$
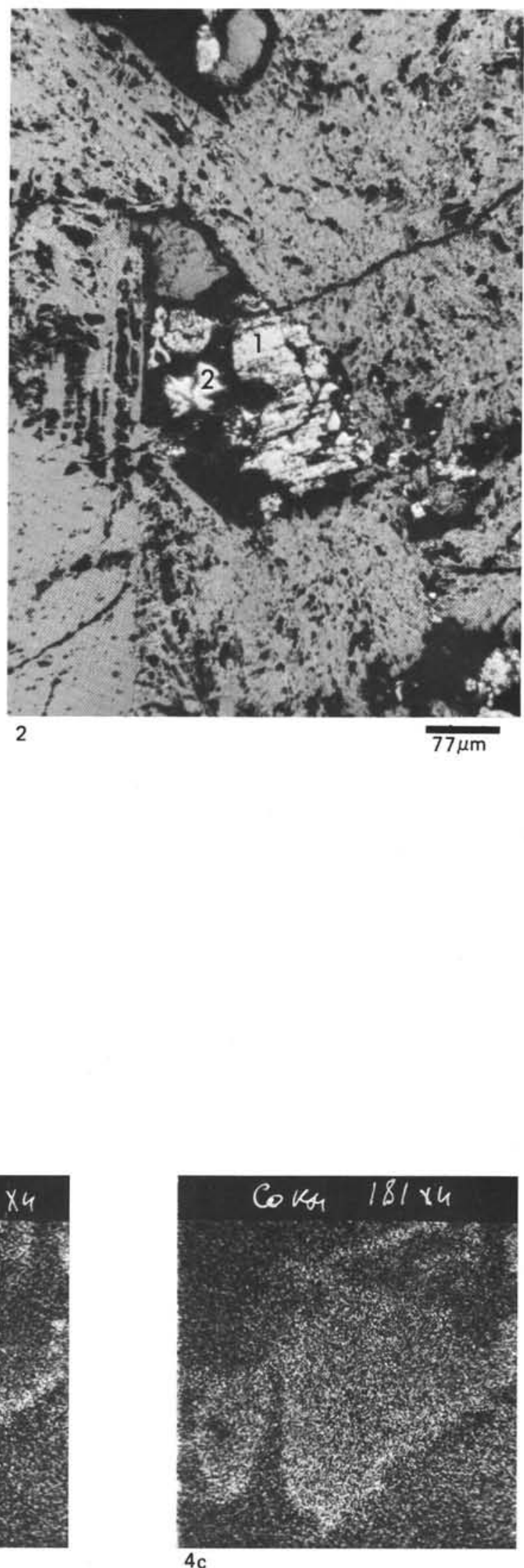
PLATE 7
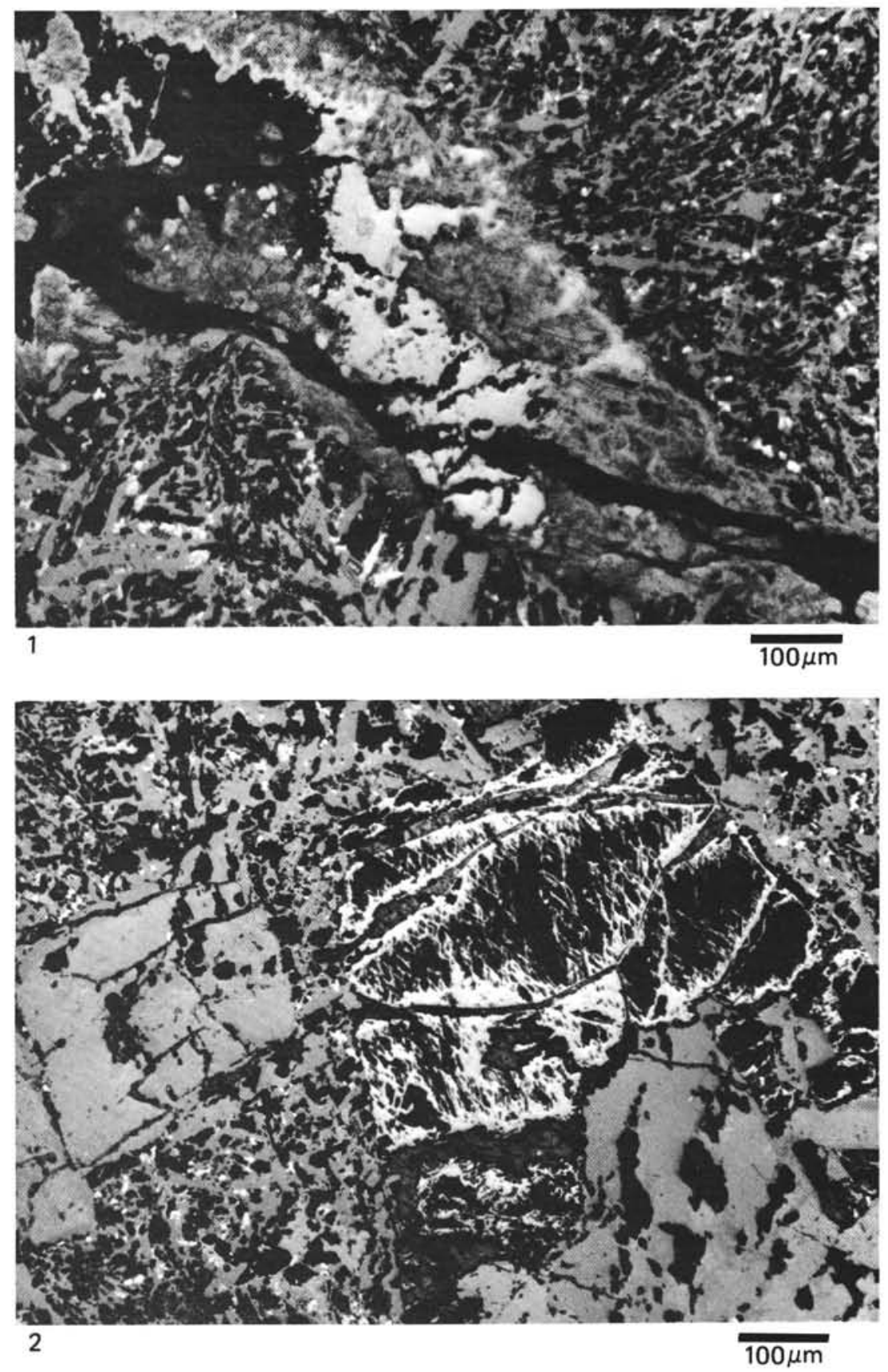

Figure 1 Iron hydroxides (light gray) in a celadonite-filled veinlet in basalt. Sample 417D-49-2, $82 \mathrm{~cm}$.

Figure 2 Iron hydroxide pseudomorphs after smectite. Sample 417D-49-2, $82 \mathrm{~cm}$. 